\title{
Surgeon factor on Laser In Situ Keratomileusis in low and moderate myopia
}

Istiantoro, Nandia Primadina

\begin{abstract}
Abstrak
Penelitian ini bertujuan mengevaluasi efektifitas dan prediktabilitas prosedur Laser in situ Keratomileusis (LASIK) pada miopia ringan dan miopia sedang, yang dikerjakan oleh tiga pembedah. Bersifat retrospektif, data diambil dari rekam medis 68 penderita (129 mata) yang menjalani prosedur LASIK. Prosedur LASIK dilakukan oleh 3 pembedah (X, Y dan Z) dengan menggunakan instrumen dan prosedur pembedahan yang sama. Pasien dikelompokkan menjadi 2 kelompok, yaitu kelompok A (kurang dari S-6.00 dioptri) dan kelompok B (S-6.00 - S-10.00 dioptri). Evaluasi tindak lanjut dilakukan pada hari ke-1, ke-7, bulan ke-1 dan ke-3. Hasil : Efektifitas dan prediktabilitas dinilai berdasarkan tajam penglihatan tanpa koreksi dan status refraksi (dalam ekuivalen sferis) yang dicapai. Sebaran korelasi antara koreksi yang diharapkan dan yang diperoleh dihitung dengan menggunakan koefisien determinasi $\left(R^{2}\right)$. Uji statistik menunjukkan hasil yang relatif sama untuk ketiga pembedah. Ternyata efektifitas dan prediktabilitas prosedur LASIK yang dilakukan oleh tiga pembedah menunjukkan hasil yang relatif sama. Faktor pembedah tampaknya tidak mempengaruhi hasil prosedur LASIK. (Med J Indones 2003; 12: 148-54)
\end{abstract}

\begin{abstract}
The purpose of this study was to evaluate the effectiveness and predictability of Laser in situ Keratomileusis (LASIK) procedure performed by three surgeons in low and moderate myopia. One hundred twenty nine eyes from 68 patients underwent LASIK procedure, performed by three different surgeons $(X, Y, Z)$ using the same procedure and same instruments were reviewed. These patients are divided into two groups, group A ( below -6.00 diopters ) and group B ( between -6.00 and -10.00 diopters ). Patients were observed on day 1 , day $7,1^{\text {st }}$ month and $3^{\text {rd }}$ month. Results: The evaluation of effectiveness and predictability is based upon uncorrected visual acuity (UCVA) and spherical equivalent refraction, respectively. The variation dispersion between attempted correction and achieved correction is measured using coefficient of determination $\left(R^{2}\right)$. The statistical analysis shows indifferent results for the three surgeons. The conclusion was that the effectiveness and predictability of LASIK procedure performed by the three surgeons in both groups are indifferent. Hence, this study suggests that the surgeon factor does not affect the result of LASIK procedure. (Med J Indones 2003; 12: 148-54)
\end{abstract}

Keywords: LASIK, spherical equivalent, visual aquity

The rapid development of refractive surgery technology has been focused on increasing effectiveness, predictability and stability of the outcome in order to serve patient satisfaction. ${ }^{1,2}$ Laser In Situ Keratomileusis (LASIK) is one of refractive surgery technique that is believed to be effective, safe, predictable, giving a fast and stable visual recovery with minimal post-operative pain. ${ }^{1-4}$ However, the technique still requires a significant surgical skill.,

The procedure of LASIK encompasses a combination of creating corneal flap using a microkeratome

Department of Ophthalmology, Faculty of Medicine, University of Indonesia/Dr. Cipto Mangunkusumo Hospital, Jakarta, Indonesia followed by refractive photo ablation on stromal bed with Argon Fluorine Excimer Laser. Corneal flap is then laid back to protect corneal epithel and Bowman membrane. ${ }^{3-7}$ This is aimed at giving a better surgical outcome i.e. faster wound recovery, minimal subepithelial haze and minimal regression. ${ }^{3,4,6-9}$

Theoretically, the LASIK standard operating procedures will give high effectiveness, predictability, and safety. ${ }^{1,8,9}$ Nevertheless, due to complex surgical procedure, the success of LASIK depends on the instruments as well as the surgeon, who should possess the skill to operate the instruments, and cooperation from the patient. ${ }^{3,4,10}$ Therefore, a question of whether different surgeons would affect LASIK results, arises. 
This article presents an evaluation of the effectiveness and predictability of LASIK procedure performed by three different surgeons in low and moderate myopia.

\section{METHODS}

\section{Patient and Study Design}

We retrospectively studied the records of patients who underwent LASIK for myopia at the Jakarta Eye Center from January 1, 1998 to December 31, 1998. The inclusion criteria were 20-30 years of age, more than 500 micron of central corneal thickness, the usage of Maria Clara nomogram in LASIK algorithm program and $160 \mu \mathrm{m}$ of corneal flap thickness. The patients were excluded from the study if there was complication during follow up. The eyes of the patients included in this study, were grouped based on the amount of preoperative spherical equivalent (SE). Group A comprised of eyes with SE less than -6.00 diopters (D) and group B with SE between -6.00 and $-10.00 \mathrm{D}$.

\section{Preoperative Examination}

Preoperative examinations comprised of an external, biomicroscopy and dilated fundus examination. Other measurements taken were keratometry and pachymetry. Visual acuity was evaluated without and with correction using Snellen chart. The result of visual acuity was converted into Snellen decimal fraction.

\section{Surgical Technique}

The LASIK procedure was performed by three experience surgeons namely $\mathrm{X}, \mathrm{Y}$ and $\mathrm{Z}$. The three surgeons performed LASIK procedure with same technique and instruments. Before performing the LASIK procedure, the patient's data were entered into Chiron 217 Excimer Laser's computer. The laser system's computer program was used to record parameters such as patient's identification and ablation depth, rate and diameter. The LASIK algorithm program was used with Maria Clara nomogram (Table 1).

Table 1. Maria Clara Nomogram

\begin{tabular}{cc}
\hline Spherical Equivalence $(\mathrm{D})$ & Correction added (D) \\
\hline 0.00 to -2.00 & -0.25 \\
-2.50 to -4.00 & -0.50 \\
-4.25 to -6.00 & -0.75 \\
$>-6.00$ & -1.00 \\
\hline
\end{tabular}

The ocular surface was anesthetized with $2 \%$ Lidocaine Hydrochloride at 30, 15 and 5 minutes before surgery. The eyelids were separated with an eyelid speculum and the eye cleaned with normal saline. A landmark was made on the cornea with gentian violet using a corneal marker. The Automated Corneal Shaper (ACS) microkeratome (Chiron Vision) and suction ring were assembled by the surgeon to make a $160 \mu \mathrm{m}$ corneal flap. Then a suction ring was applied, centered on the previous marks. Intraocular pressure (IOP) was verified to be greater than $65 \mathrm{mmHg}$ with Barraquer tonometer.

The corneal surface was irrigated with Balance Salt Solution (BSS) and the microkeratome head placed in position to produce a corneal flap. After the corneal flap was formed, the microkeratome and suction ring were removed and the flap was reflected nasally. The exposed stromal bed must be in the dry condition before ready for laser ablation.

An ArF excimer laser system (Chiron 217) was used to correct refractive errors. The excimer laser produced $193 \mathrm{~nm}$ ultraviolet light with a fluence of $160 \mathrm{~mJ} / \mathrm{cm}^{2}$ and a pulse rate of $5 \mathrm{~Hz}$. Before ablation, the patient must fixated the eye to green fixation light.

After excimer laser ablation, the ablated stromal bed was irrigated with BSS. The corneal bed and the inner surface of the flap were dried with micro sponges, and the flap was realigned with the marks to its original position. Striae test was performed to determine whether the flap had been properly seated and forming a good adhesion with stromal bed. At the end of the surgery, Chloramphenicol $0.5 \%$ eye drops were instilled into that eye and continued to instill three times daily for 7 days. Eyes were protected with a clear shield after surgery.

\section{Post-operative Examination}

Follow-up examinations were scheduled for day 1, day 7 , the first and third month post ope-ratively. The examinations included visual acuity without and with correction.

The result was used to evaluate the effectiveness and the predictability for each surgeons. Effectiveness is the best result achieved from LASIK procedure and measured as uncorrected visual acuity (UCVA). Predictability is the accuracy of the result compared to predicted outcome and calculated as refractive correction in SE. 


\section{RESULTS}

Sixty-eight patients (129 eyes) underwent LASIK procedures for myopia correction between January 1,1998 and December 31,1998.

Surgeon $\mathrm{X}$ performed LASIK procedure on 21 patients (30 eyes) and all eyes were included in this study. From 30 eyes, 13 eyes were put in- group A and 17 eyes were in-group B. Surgeon Y had LASIK procedure on 24 patients (49 eyes) and all eyes were included in this study. Thirty-five eyes were in-group $\mathrm{A}$ and 14 eyes were in-group B. Surgeon $\mathrm{Z}$ performed LASIK procedure on 23 patients (50 eyes) and all eyes were included in this study. From 50 eyes, 39 were in-group A and 11 were in-group B.

The mean of preoperative UCVA in both groups of surgeon $\mathrm{X}$ was $0.075 \pm 0.015$ and the mean of SE was $5.778 \pm 1.88$, and the mean of cylinder was $-0.73 \pm 0.69$. For both groups of surgeon $\mathrm{Y}$, the mean of preoperative UCVA was $0.069 \pm 0.08$, and the mean of SE was $4.689 \pm 1.78$ and the mean of cylinder was $-1.267 \pm$ 1.26. Both groups of surgeon $\mathrm{Z}$ had preoperative UCVA mean of $0.076 \pm 0.07$ and SE mean of $-4.652 \pm 1.59$ and cylinder mean of $-0.875 \pm 0.58$.

In-group A, follow-up patients from surgeon $\mathrm{X}$ were 13 eyes at day 1,12 eyes at day 7,11 eyes at the first month and only 3 eyes at the third month. In-group B,
17 eyes were followed-up at day 1,16 eyes at day 7 , 13 eyes at the first month and 16 eyes at the third month.

Of surgeon Y, follow-up patients (group A) at day 1 were 35 eyes, 32 eyes at day 7, 31 eyes at the first month and 16 eyes at the third month. In-group B, follow-up was obtained for 14 eyes at day 1, 13 eyes at day 7, 10 eyes at the first month and 8 eyes at the third month.

For surgeon Z's group A, the follow-up eyes were 39 at day 1, 39 eyes at day 7,28 eyes at the first month and 23 eyes at the third month. In-group B, follow-up was obtained for 11 eyes at day 1,11 eyes at day 7,8 eyes at the first month and 3 eyes at the third month.

Table 2 shows refractive data for group A and BIn both groups, there were tendencies of spherical over correction, except of surgeon $\mathrm{X}$ in-group $\mathrm{A}$ which the tendency becoming myopic after $3^{\text {rd }}$ month. However, the spherical equivalent over-correction in both groups for all surgeons was less than $1.00 \mathrm{D}$.

In table 3 , it can be seen that surgeon X has $100 \%$ of $\mathrm{UCVA} \geq 0.5$, and for surgeon $\mathrm{Z}$, it was achieved at $1^{\text {st }}$ and $3^{\text {rd }}$ month follow-up, while for surgeon $\mathrm{Y}$, the $100 \%$ of UCVA $\geq 0.5$ was reached at $3^{\text {rd }}$ month.

In-group B, $100 \%$ of UCVA $\geq 0.5$ was achieved by surgeon $\mathrm{Y}$ and $\mathrm{Z}$ at $1^{\text {st }}$ and $3^{\text {rd }}$ month follow-up, while for surgeon $X$, by $3^{\text {rd }}$ month the percentage was only at $87.50 \%$.

Table 2. Refractive results for Group A and B

\begin{tabular}{|c|c|c|c|c|c|c|c|}
\hline \multirow[b]{2}{*}{ Surgeon } & \multirow{2}{*}{$\begin{array}{l}\text { Follow-up } \\
\text { schedule }\end{array}$} & \multicolumn{3}{|c|}{ Group A } & \multicolumn{3}{|c|}{ Group B } \\
\hline & & $\begin{array}{c}\text { Number of } \\
\text { Eyes }\end{array}$ & $\begin{array}{c}\text { UCVA } \\
\text { Mean } \pm \text { SD }\end{array}$ & $\begin{array}{l}\text { Spher. Eq. } \\
\text { Mean } \pm \text { SD }\end{array}$ & $\begin{array}{c}\text { Number of } \\
\text { Eyes }\end{array}$ & $\begin{array}{c}\text { UCVA } \\
\text { Mean } \pm \text { SD }\end{array}$ & $\begin{array}{l}\text { Spher. Eq. } \\
\text { Mean } \pm \text { SD }\end{array}$ \\
\hline \multirow[t]{5}{*}{$\mathbf{X}$} & Pre-op & 13 & $0.113 \pm 0.15$ & $-4.125 \pm 1.28$ & 17 & $0.047 \pm 0.02$ & $-7.051 \pm 1.12$ \\
\hline & Day 1 & 13 & $0.862 \pm 0.13$ & $0.346 \pm 0.46$ & 17 & $0.565 \pm 0.24$ & $0.838 \pm 0.89$ \\
\hline & Day 7 & 12 & $0.900+0.11$ & $0.229+0.36$ & 16 & $0.631+0.28$ & $0.539+0.63$ \\
\hline & $1^{\text {st }}$ month & 11 & $0.936 \pm 0.12$ & $0.182 \pm 0.25$ & 13 & $0.754 \pm 0.19$ & $0.481 \pm 0.68$ \\
\hline & $3^{\text {rd }}$ month & 3 & $0.867 \pm 0.23$ & $-0.125 \pm 0.22$ & 16 & $0.744 \pm 0.22$ & $0.273 \pm 0.57$ \\
\hline \multirow[t]{5}{*}{$\mathbf{Y}$} & Pre-op & 35 & $0.081 \pm 0.09$ & $-3.821 \pm 1.21$ & 14 & $0.042 \pm 0.01$ & $-6.857 \pm 0.92$ \\
\hline & Day 1 & 35 & $0.803 \pm 0.20$ & $0.296 \pm 0.57$ & 14 & $0.714 \pm 0.28$ & $0.830 \pm 0.82$ \\
\hline & Day 7 & 32 & $0.834 \pm 0.20$ & $0.191 \pm 0.43$ & 13 & $0.769 \pm 0.29$ & $0.471 \pm 0.82$ \\
\hline & $1^{\text {st }}$ month & 31 & $0.839+0.21$ & $0.190+0.38$ & 10 & $0.88+0.17$ & $0.15+0.32$ \\
\hline & $3^{\text {rd }}$ month & 16 & $0.863 \pm 0.17$ & $0.094 \pm 0.25$ & 8 & $0.9 \pm 0.09$ & $0.109 \pm 0.18$ \\
\hline \multirow[t]{5}{*}{$\mathbf{Z}$} & Pre-op & 39 & $0.087 \pm 0.08$ & $-4.019 \pm 1.14$ & 11 & $0.038 \pm 0.02$ & $-6.898 \pm 0.70$ \\
\hline & Day 1 & 39 & $0.799 \pm 0.18$ & $0.516 \pm 0.59$ & 11 & $0.718 \pm 0.29$ & $0.750 \pm 0.66$ \\
\hline & Day 7 & 39 & $0.887 \pm 0.16$ & $0.202 \pm 0.36$ & 11 & $0.827 \pm 0.25$ & $0.318+0.46$ \\
\hline & $1^{\text {st }}$ month & 28 & $0.939+0.09$ & $0.022+0.17$ & 8 & $0.962+0.05$ & $0.125+0.23$ \\
\hline & $3^{\text {rd }}$ month & 23 & $0.951 \pm 0.09$ & $0.027 \pm 0.18$ & 3 & $1.00 \pm 0.00$ & $0.083 \pm 0.14$ \\
\hline
\end{tabular}


It can be seen from the scatter plot below, that there is a tendency of over correction with coefficient of determinant $\left(\mathrm{R}^{2}\right)$ of 0.9577 .
This tendency can also be seen in figure 2 (for surgeon $\mathrm{Y}$ ) and figure 3 (for surgeon $\mathrm{Z}$ ) where the coefficients of determinants (R2) were 0.939 and 0.9723 respectively.

Table 3. Uncorrected Visual Acuity (UCVA) results (\%)

\begin{tabular}{|c|c|c|c|c|c|c|c|c|c|}
\hline \multirow{2}{*}{ Group A } & \multicolumn{3}{|c|}{$\mathbf{X}$} & \multicolumn{3}{|c|}{$\bar{Y}$} & \multicolumn{3}{|c|}{$\mathbf{Z}$} \\
\hline & $\geq 0.8$ & $\begin{array}{l}<0.8 \\
\geq 0.5\end{array}$ & $<0.5$ & $\geq 0.8$ & $\begin{array}{l}<0.8 \\
\geq 0.5\end{array}$ & $<0.5$ & $\geq 0.8$ & $\begin{array}{l}<0.8 \\
\geq 0.5\end{array}$ & $<0.5$ \\
\hline $1^{\text {st }}$ day & $84.62 \%$ & $15.38 \%$ & $0 \%$ & $74.29 \%$ & $17.14 \%$ & $8.57 \%$ & $66.67 \%$ & $28.20 \%$ & $5.13 \%$ \\
\hline $7^{\text {th }}$ day & $83.33 \%$ & $16.67 \%$ & $0 \%$ & $68.75 \%$ & $28.13 \%$ & $3.13 \%$ & $79.49 \%$ & $17.95 \%$ & $2.56 \%$ \\
\hline $1^{\text {st }} \mathrm{mth}$ & $81.82 \%$ & $18.18 \%$ & $0 \%$ & $70.97 \%$ & $19.35 \%$ & $9.68 \%$ & $92.86 \%$ & $7.14 \%$ & $0 \%$ \\
\hline $3^{\text {rd }} \mathrm{mth}$ & $66.67 \%$ & $33.33 \%$ & $0 \%$ & $87.50 \%$ & $12.50 \%$ & $0 \%$ & $95.65 \%$ & $4.35 \%$ & $0 \%$ \\
\hline \multirow{2}{*}{ Group B } & \multicolumn{3}{|c|}{$\mathbf{x}$} & \multicolumn{3}{|c|}{$\mathbf{Y}$} & \multicolumn{3}{|c|}{$\mathbf{Z}$} \\
\hline & $\geq 0.8$ & $\begin{array}{l}<0.8 \\
\geq 0.5\end{array}$ & $<0.5$ & $\geq 0.8$ & $\begin{array}{l}<0.8 \\
\geq 0.5\end{array}$ & $<0.5$ & $\geq 0.8$ & $\begin{array}{l}<0.8 \\
\geq 0.5\end{array}$ & $<0.5$ \\
\hline $1^{\text {st }}$ day & $23.53 \%$ & $47.06 \%$ & $29.41 \%$ & $50.00 \%$ & $35.71 \%$ & $14.29 \%$ & $63.63 \%$ & $18.08 \%$ & $18.08 \%$ \\
\hline $7^{\text {th }}$ day & $37.50 \%$ & $43.75 \%$ & $18.75 \%$ & $69.23 \%$ & $15.38 \%$ & $15.38 \%$ & $72.73 \%$ & $18.08 \%$ & $9.09 \%$ \\
\hline $1^{\text {st }} \mathrm{mth}$ & $69.23 \%$ & $23.08 \%$ & $7.69 \%$ & $80.00 \%$ & $20.00 \%$ & $0 \%$ & $100 \%$ & $0 \%$ & $0 \%$ \\
\hline $3^{\text {rd }} \mathrm{mth}$ & $56.25 \%$ & $31.25 \%$ & $12.50 \%$ & $87.50 \%$ & $12.50 \%$ & $0 \%$ & $100 \%$ & $0 \%$ & $0 \%$ \\
\hline
\end{tabular}

Figure 1. Scattered plot of attempted vs. achieved correction at $3^{\text {rd }}$ month (surgeon X)

Figure 2. Scattered plot of attempted vs. achieved correction at $3^{\text {rd }}$ month (surgeon Y) 


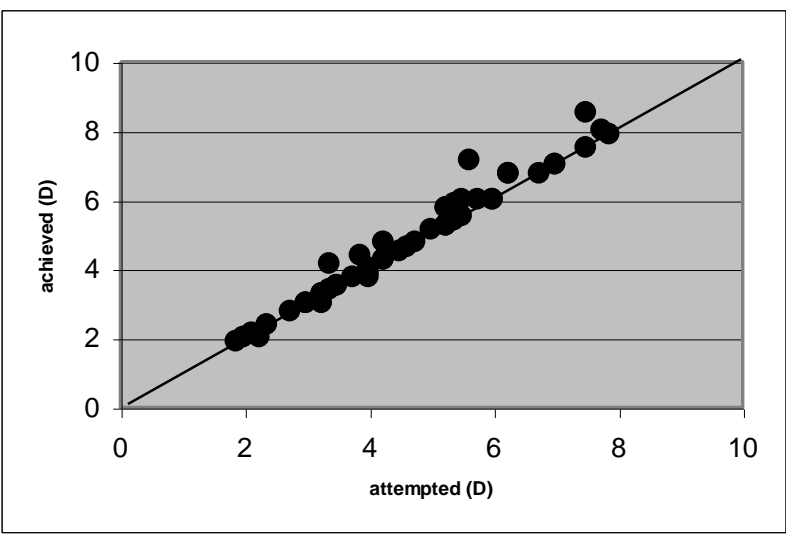

Figure 3. Scattered plot of attempted vs. achieved correction at $3^{\text {rd }}$ month (surgeon $Z$ )

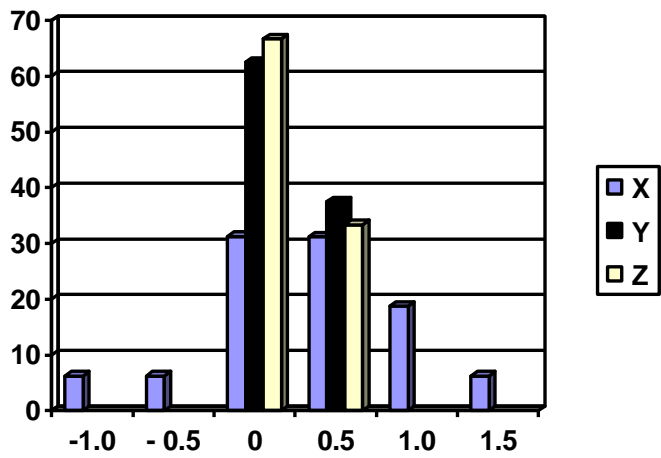

Figure 4. Spherical equivalent refractive outcome in-group A at $3^{\text {rd }}$ month follow-up

Figure 4 shows that the predictability measured by spherical equivalent outcome for surgeon $\mathrm{X}$ and $\mathrm{Z}$ were $100 \%$ within $\pm 0.5 \mathrm{D}$. Whilst by surgeon $\mathrm{Y}$, $93.75 \%$ predictability were within $\pm 0.5 \mathrm{D}$.
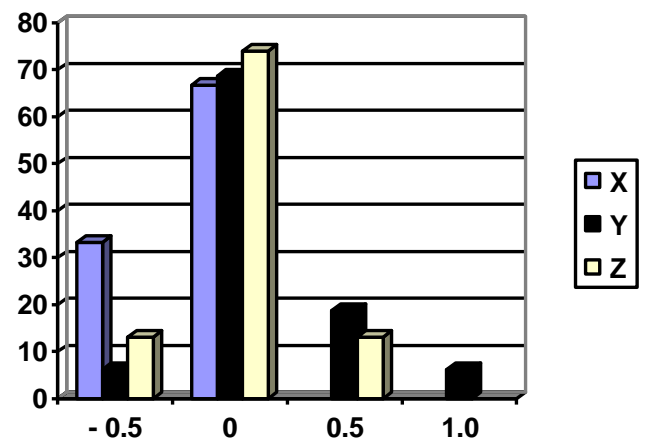

Figure 5. Spherical equivalent refractive outcome in-group $B$ at $3^{\text {rd }}$ month follow-up
On the other hand, in-group B, $100 \%$ predictability within $\pm 0.5 \mathrm{D}$ was achieved by surgeon $\mathrm{Y}$ and $\mathrm{Z}$, while surgeon $\mathrm{X}$ had only the predictability of $68.75 \%$. (Figure 5)

\section{DISCUSSION}

Presently, LASIK technique is believed as a corneal refractive surgery with high effectiveness, high predictability and good refraction stability., ${ }^{1,8}$ Nevertheless, the satis-fied result can only be attained if the patient, surgeon and instruments are well prepared. ${ }^{3,4}$ The LASIK technique is not fully dependent on the instruments, but it needs experienced surgeon and cooperation from the patient. ${ }^{10}$

This study reveals that the result of UCVA $\geq 0.5$ ingroup A was $100 \%$ achieved by surgeon $\mathrm{X}$ and $\mathrm{Z}$ at $1^{\text {st }}$ and $3^{\text {rd }}$ month follow-up, while surgeon $\mathrm{Y}$ was reached the same percentage at $3^{\text {rd }}$ month follow-up. In-group $\mathrm{B}, \mathrm{UCVA} \geq 0.5$ was $100 \%$ achieved by surgeon $\mathrm{Y}$ and $\mathrm{Z}$ at $1^{\mathrm{st}}$ and $3^{\text {rd }}$ month follow-up. The achievement of surgeon $X$ was less than of the two surgeons, i.e. $92.31 \%$ at $1^{\text {st }}$ month follow-up and $87.50 \%$ at $3^{\text {rd }}$ month follow-up.

Maldonado et $\mathrm{al}^{11}$ reported the UCVA $\geq 0.5$ in myopia between $-3.00 \mathrm{D}$ and $-6.00 \mathrm{D}$ was $96.43 \%$, while for myopia between $-6.25 \mathrm{D}$ and $-10.00 \mathrm{D}$ was $76.64 \%$. Knorz et $\mathrm{al}^{12}$ also found the UCVA $\geq 0.5$ in myopia between $-5.00 \mathrm{D}$ and $-9.90 \mathrm{D}$ was 71 to $88 \%$, and for myopia between $-10.00 \mathrm{D}$ and -14.90 $\mathrm{D}$ was decreased to $33 \%$. The study of Salchow et al ${ }^{7}$ describe that the UCVA $\geq 0.5$ for myopia between $1.50 \mathrm{D}$ and $-16.00 \mathrm{D}$ is $82.50 \%$.

This study suggests a similar outcome to those previous study. For certain result, this study is even better than the previous study. The UCVA $\geq 0.5$ was achieved $100 \%$ by surgeon $\mathrm{X}, \mathrm{Y}$ and $\mathrm{Z}$ in-group $\mathrm{A}$ and by surgeon $\mathrm{Y}$ and $\mathrm{Z}$ in-group $\mathrm{B}$.

Predictability in-group A was $100 \%$ within $\pm 1.00 \mathrm{D}$ at $1^{\text {st }}$ and $3^{\text {rd }}$ month follow-up for all surgeons. In fact, predictability for surgeon $\mathrm{X}$ and $\mathrm{Z}$ were $100 \%$ within $\pm 0.5 \mathrm{D}$, while for surgeon $\mathrm{Y}$ is less than of the two surgeons, i.e. $90.42 \%$. In-group B, the predictability is less than group A for all surgeons. Surgeon Y and $\mathrm{Z}$ have predictability of $100 \%$ within $\pm 1.00 \mathrm{D}$, and for surgeon $\mathrm{X}$ the percentage is $89.19 \%$. 
Salchow et $\mathrm{al}^{7}$ reported that predictability for myopia between $-1.50 \mathrm{D}$ and $-16.00 \mathrm{D}$ was $81 \%$ within \pm 1.00 D. On the other hand, Maldonado et al $^{11}$ reported that predictability for myopia between $-3.00 \mathrm{D}$ and -6.00 $\mathrm{D}$ was $82.14 \%$ within $\pm 1.00 \mathrm{D}$, but the result was decreased to $58.70 \%$ for myopia between $-6.25 \mathrm{D}$ and $-10.00 \mathrm{D}$. The predictability in this study seems better than of Maldonado, i.e. 89.19-100\% within \pm 1.00 D. The result of this study is also indifferent with of Knorz et $\mathrm{al}^{7}$. The predictability is $100 \%$ within \pm 1.00 $\mathrm{D}$ for low and moderate myopia, but for high myopia (more than $-15.00 \mathrm{D}$ ) the predictability is decreased to $38.9 \%$.

This study shows high effectiveness and predictability for all surgeons in low and moderate myopia, although the outcome is not exactly the same. The effectiveness and predictability for surgeon $\mathrm{Z}$ is good in both low and moderate myopia, while surgeon $\mathrm{Y}$ is good in moderate myopia and surgeon $\mathrm{X}$ is in low myopia. Based on the scatter diagrams of attempted correction versus achieved correction, all three surgeons come up with high coefficients of determinant between 0.93 to 0.97 . This implies that the three surgeons have similar results.

Several factors can influence the effectiveness and predictability of LASIK procedure namely the instruments, the surgeon and the patient. ${ }^{3,4}$

The excimer laser machine has a specific ablation homogenecity which can influence the accuracy of LASIK procedure's result, since it produces the clinical profile which determine the predictabiliy and refraction stability, also the complication possibility such as central islands. ${ }^{3}$

In this study, all of the surgeons use the same excimer laser machine, so the different result among surgeons is not because of the machine. However, the different result can be caused by different estimation when the surgeons performing ablation laser beam test. ${ }^{3,4}$

The excimer laser computer algorithm calculates the amount of ablation based on corneal thickness, ablation diamater and spherical correction using normogram in order to obtain the correction result as predicted. The use of normogram is aimed at minimizing undercorrection as well as overcorrection. ${ }^{3,4,13}$

Since all surgeons in this study use same Maria Clara normogram, so there will be no different of amount correction calculated by the machine.
The laser machine and microkeratome are automated. Once the microkeratome begins to progress the cornea and the excimer laser begins its ablation, the surgeon does not have control over the instrument. ${ }^{13}$ Therefore, the instrument preparation such as microkeratome assembling and examination, and ablation laser beam test must be prepared well before the surgery. ${ }^{3,4,13}$

For those reasons, the surgeon skill in performing and authorizing LASIK's instrument is absolutely needed in order to obtain a satisfied result. ${ }^{13}$

The surgeon, for example, has to put the suction ring on the central cornea to make a good flap which will give a good focus and centration of ablation.,

On the other hand, hydration level when the automated corneal shaper (ACS) moving can influence the accuracy of LASIK procedure. Wet surface of the cornea can break the microkeratome's motor and this will influence the progress of microkeratome on corneal surface. Stromal hydration level in ablation progress can also influence the result of LASIK procedure. Wet corneal surface can interfere the laser beam, which increase the risk of overcorrection and central islands. ${ }^{3,4}$

The effectiveness and predictability are also dependent to cooperation between patient and surgeon. Eye movement and poor fixation while the ablation progressing can influence the refraction result. ${ }^{3,4}$ The patient must fixate the eye to green light fixation to avoid ablation decentration. However, in this study the surgeons use the eye tracker to avoid the decentration. ${ }^{14,15}$

Hence, different effectiveness and predictability of the results might be caused by surgeon factor as explained before.

This study, however shows that effectiveness and predictability by three surgeons performed LASIK procedure using the same procedure and instruments are indifferent. In conclusion, its seem that the surgeon factor does not affect the LASIK results.

\section{REFERENCES}

1. American Academy of Ophthalmology Staff. Corneal Surgery. In: Denny M, Taylor F eds. External disease and cornea. Basic and clinical science course. Section 8. San Fransisco: American Academy of Ophthalmology; 1997. p.315-47. 
2. Reviglio VE, Luna JP, Rodriquez ML, Garcia FE, Juarez CP. Laser in situ keratomileusis using the laser sight 200 laser: result of 950 consecutive cases. J Cataract Refract Surg 1999; 25: 1062-8.

3. Machat JJ, Excimer laser refractive surgery, Practice and principles. Thorofare: SLACK Incorporated; 1996.p.267357.

4. Buratto L, Brint SF, Ferrari M. LASIK Principles and Techniques. Thorofare: SLACK Incorporated; 1998.p.3-133.

5. Perez-Santonja JJ, Ayala MJ, Sakla HF, Ruiz-Moreno JM, Alio JL. Retreatment after laser in situ kleratomileusis. Ophthalmology 1999; 1: 21-7.

6. Chiron Vision Corp. LASIK: Lamellar refractive surgery. In: Casebeer JC, Slade SG eds. LASIK Lamellar refractive surgery: technique, technology and complications. Chiron Vision Corp. 1996.

7. Salchow DJ, Zirm ME, Stieldorf C, Parisi A. Laser in situ keratomileusis for myopia and myopic astigmatism. J Cataract Refract Surg 1998; 24: 175-82.

8. Danasoury MA, Maghraby AE, Klyce SD, Mehrez K. Comparison of Photo-refractive keratectomy with Laser in situ keratomileusis in correcting low myopia (from -2.00 to -5.50 diopters). A randomized study. Ophthalmology 1999; 106: 411-20.

9. Zaldivar R, Davidorf JM, Shultz MC, Oscherow S. Laser in situ keratomileusis for low myopia and astigmatism with a scanning spot excimer laser. J Refract Surg 1997; 13: 614-19.

10. Davidorf JM, Zaldivar R, Oscherow S. Results and complications of Laser in situ keratomileusis by experienced surgeons. J Refract Surg 1998; 14: 114-22.

11. Maldonado A, Onnis R. Result of Laser in situ keratomileusis in different degrees in myopia. Opthalmology 1998;105: 606-11.

12. Knorz MC, Wiesinger B, Liermann A, Seiberth V, Liesenhoff $\mathrm{H}$. Laser in situ keratomileusis for moderate and high myopia and myopic astigmatism. Ophthalmology 1998; 105: 932-40.

13. Salah T, Waring III GO, Maghraby AE, Moadel K, Grimm SB. Excimer laser in situ kerato-mileusis under a corneal flap for myopia of 2 to 20 diopters. Am J Ophthalmol 1996; 121: 143-55.

14. Schwiegerling J, Snyder RW. Eye movement during laser in situ keratomileusis. J Cataract Refract Surg 2000; 26: 345-51.

15. Tsai YY, Lin JM. Ablation centration after active eyetracker-assisted photorefractive keratec-tomy and laser in situ keratomileusis. J Cataract Refract Surg 2000; 26 : 2834. 
